(C) 1983 ISIJ

\title{
Analysis of Blowhole Formation and Suppression during Solidification by Cold Model
}

\section{Ei-ichi Takeuchi, Hiromu FuJI-I, Tetsuro OHashi, and Masahiko Shinonmatsu}

\section{Synopsis :}

$\mathrm{CO}$ blowhole formation on the surface of the continuously cast slab is one of the most important problems in continuous casting of slightly deoxidized steel, such as pseudo-rimmed steel.

Model experiment with aerated water was carried out in order to understand the mechanism of CO blowhole formation and suppression with molten flow during solidification of steel.

The results obtained are summarized as follows.

1) Equilibrium distribution constant of $\mathrm{CO}_{2}$ is estimated to evaluate the $\mathrm{CO}_{2}$ blowhole formation and suppression quantitatively.

2) The shape of $\mathrm{CO}_{2}$ blowholes chiefly depends on the concentration of $\mathrm{CO}_{2}$ at the solidification front and the solidification rate.

3) $\mathrm{CO}_{2}$ blowholes are suppressed completely with fluid flow at the certain velosity which is related to $\mathrm{CO}_{2}$ content of aerated water.

4) The models of blowhole formation and suppression based of the experimental results are proposed. The calculated results agree well with the measured value.

\section{1. 緒言}

連鋳々片に打ける表面気孔の発生は熱間圧延時にコイ ル表面疵となり成品の歩留りを著しく阻害する。この気 孔発生をコントロールすることは抲脱酸鋼1) 3)，さらに はリムド相当材等の未脱酸鋼の連鋳化 ${ }^{4) 5}$ ) を行ら上で極 めて重要な問題である. しかしながら鉄凝固時の気孔生 成については幾つかの報告6) 11) はあるものの実用鋼連 鋳時の気孔生成，さらにその抑制に関する研究例は極め て少ない. 本研究は鉄凝固時の $\mathrm{CO}$ 気孔の生成メカ二 ズム，さらには効果的な抑制についての基礎的知見を得 るべく，条件設定，観察の容易な炭酸水凝固のモデル実 験を行い，炭酸水凝固時の $\mathrm{CO}_{2}$ 気孔の生成之流動によ る抑制について検討を行つたものである. 凝固時の気孔 生成に関するモデル解析については，空気あるいは酸素 ガスの水溶液を用いた $A . E . \mathrm{CARTER}^{12)}, W . A$. Hills $ら^{13)}$ の報告があるが，これらは主として溶質がスの固液 分配について述べたものであり, 気孔生成については観 察の域にとどまつている.

本研究では炭酸水凝固時の $\mathrm{CO}_{2}$ 気孔の生成と流動に
よる抑制の 現象を 観察するとともに，液相，固相中の $\mathrm{CO}_{2}$ 濃度, 凝固速度, 溶液の流速分布の測定をするこ とにより，これらの現象を定量的に把握することを試み た.

\section{2. 実 験 方 法}

実験装置の概要を Fig. 1 に示す。装置は中間に 2.5 $\mathrm{mm}$ 厚の銅板を介した二槽容器, および溶液攪汼のため の回転子から成り,一方の槽に冷却剂としてェチルアル コールとドライアイス，他方の槽には所定の濃度に調整 した炭酸水溶液を入れ，これを一方向凝固させるもので ある.なお容器は透明アクリル製で凝固厚みの時間変化 の測定, 気孔発生状況の観測を外部から連続的に行える ようにした，炭酸水溶液中に浸漬した回転子は凝固界面 の前進速度と同じ速度で凝固進行方向に移動させること により, 凝固開始から終了時にわたつて所定の流速の流 動を凝固前面に付与することが可能である．炭酸水溶液 は蒸留水に! $\mathrm{CO}_{2}{ }^{\circ}$ ガスを溶解させ, 所定の $\mathrm{CO}_{2}$ 濃度, 温度に調整して使用した. 炭酸水溶液を静止または攪挥 しながら一方向凝固させ，凝固シェル厚，溶液バルク中

昭和 56 年 4 月本会講演大会にて発表 昭和 57 年 11 月 25 日受付 (Received Nov. 25，1982)

* 新日本製鉄 (株) 本社 (Nippon Steel Corp.)

*2 新日本製鉄 (株) 広畑製鉄所 (Hirohata Works, Nippon Steel Corp., 1 Fuji-cho Hirohata-ku Himeji 671-11)

*3 新日本製鉄 (株) 広畑製鉄所 工博 (Hirohata Works, Nippon Steel Corp.) 


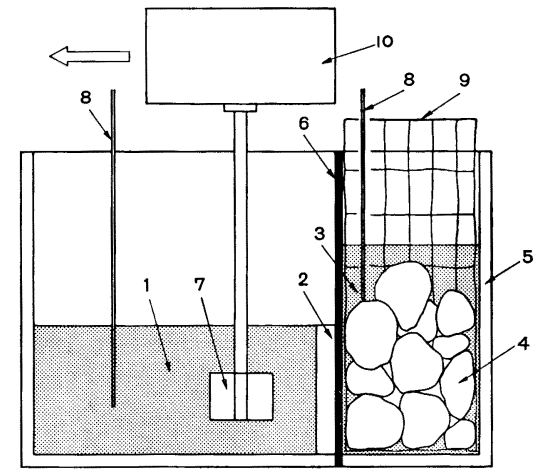

1. aerated water 2. ice 3. ethyl-alcohol 4. dry ice 5. acrylic resin 6. Cu plate 7. stirrer 8. thermocouple 9. steel net 10. driving unit

Fig. 1. Schematic view of experimental apparatus.

の $\mathrm{CO}_{2}$ 濃度, および温度の時間変化を測定した. 実験 終了後, 凝固進行方向に沿つて凝固シェルを切断し, 断 面の $\mathrm{CO}_{2}$ 気孔発生状況の観察, 気孔形状の測定, およ び写真撮影を行つた. またシェルの見かけの体積, 重量 より気孔発生量を算出した. 攪拌によつて生ずる凝固前 面の流速はアネモメータ,およびトレーサー法により実 測した. その結果, 槽の底部, コーナー部に淀みを生ず るものの比較的均一な流速分布となる凝固面が存在する ことが分かり，この部位を対象にして調査を行つた. 凝 固シェル中の $\mathrm{CO}_{2}$ 濃度はシェルの所定の位置を $2 \mathrm{~mm}$ の厚みにわたり削り出し, これを $\mathrm{CO}_{2}$ 吸収液中に溶解 して定量した. 吸収液は $10 \% \mathrm{BaCl}_{2}$ 水溶液を $20 \mathrm{cc}$ と $\mathrm{N} / 25 \mathrm{NaOH}$ 水溶液を $30 \mathrm{cc}$ 混合したものを用い, この 中に $\mathrm{CO}_{2}$ を $\mathrm{BaCO}_{3}$ として固定後, $\mathrm{N} / 25 \mathrm{HCl}$ 水溶液 にて中和滴定して $\mathrm{CO}_{2}$ 濃度を定量したが，分析精度の 点からこれらの操作はすべて窒素ガスシール下で行つ た.

\section{3. 実 験 結 果}

\section{1 炭酸水凝固時の $\mathrm{CO}_{2}$ 固液分配}

炭酸水凝固時の気孔発生を定量化するにあたつては, 溶鋼の場合之同様, 気孔を構成する溶質成分 $\mathrm{CO}_{2}$ の固 液分配に関するデータが必要である. しかしながら，こ れに関する報告は無く本実験を行らにあたつてあらかじ め固液分配係数の 測定を行つた. 凝固シェル中に $\mathrm{CO}_{2}$ 気孔が発生するような条件下では分配係数の正確な測定 ができないため, これらの実験は気孔発生の無い低 $\mathrm{CO}_{2}$ 濃度域で行つた.

バルク溶液中の温度 $T_{\mathrm{I}}$ は約 $3^{\circ} \mathrm{C}$, 冷却剤の温度 $T_{\text {II }}$ は $-72^{\circ} \mathrm{C}$ と一定条件で，凝固速度定数も 0.75 $\mathrm{mm} / \mathrm{s}^{1 / 2}$ とほぼ一定であつた。.シェル厚が $1 \sim 12 \mathrm{~mm}$

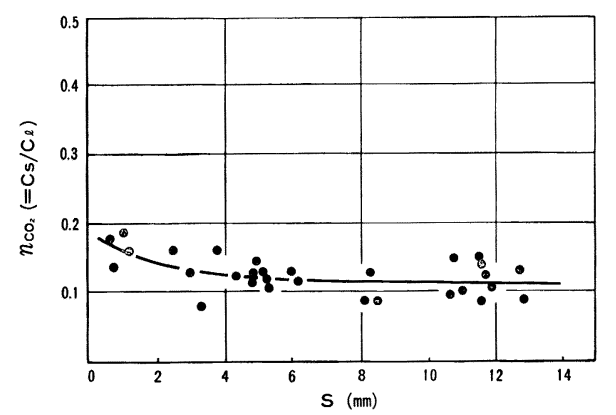

Fig. 2. Relationship between shell thickness and effective distribution coefficient.

Table 1. Experimental results for formation of $\mathrm{CO}_{2}$ blowholes.

\begin{tabular}{|c|r|r|r|r|c|}
\hline Exp. No & $\mathrm{C}_{\ell}(\mathrm{mg} / \mathrm{l})$ & $\mathrm{T}_{\mathrm{I}}\left({ }^{\circ} \mathrm{C}\right)$ & $\left.\mathrm{T}_{\mathrm{II}}{ }^{\circ} \mathrm{C} \mathrm{C}\right)$ & $\mathrm{k}\left(\mathrm{mm} / \mathrm{sec}^{\mathrm{i}}\right)$ & blowholes \\
\hline $\mathrm{A}-1$ & 80 & 3.0 & -70 & 0.78 & $\bigcirc$ \\
-2 & 195 & 3.0 & -70 & 0.73 & 0 \\
-3 & 231 & 3.5 & -69 & 0.75 & 0 \\
-4 & 275 & 3.0 & -72 & 0.73 & 0 \\
-5 & 500 & 3.0 & -70 & 0.71 & $\bullet$ \\
-6 & 565 & 3.0 & -72 & 0.72 & $\bullet$ \\
-7 & 950 & 3.5 & -70 & 0.73 & $\bullet$ \\
-8 & 1.051 & 3.0 & -72 & 0.72 & $\bullet$ \\
-9 & 1.900 & 3.0 & -70 & 0.69 & $\bullet$ \\
-10 & 1.913 & 3.0 & -72 & 0.70 & $\bullet$ \\
-11 & 2.715 & 3.0 & -72 & 0.69 & $\bullet$ \\
-12 & 2.740 & 3.0 & -70 & 0.68 & $\bullet$ \\
\hline
\end{tabular}

のところでシェルを取り出し，これを定量分析して(1) 式のごとく実効分配係数 $n_{\mathrm{CO}_{2}}$ を算出した.

$$
n_{\mathrm{CO}_{2}}=C_{\mathrm{s}} / C_{1}
$$

なお $C_{\mathrm{s}}, C_{1}$ はそれぞれ凝固シェル中およびバルク溶 液中の $\mathrm{CO}_{2}$ 濃度である.

Fig. 2 は以上の実験結果に基づき凝固シェル厚 $S$ と 実効分配係数の関係をプロットしたものである．凝固初 期に打いて㬰効分配係数の值は 0.20 から 0.15 へと変 化するがシェル厚が $5 \mathrm{~mm}$ 以上の位置ではその值の変化 は小さくなつている. この実効分配係数の值とのものに ついては固相中の $\mathrm{CO}_{2}$ 濃度の測定精度上問 題 は残 る が，マクロ的には問題ないと判断し解析に使用した.

\section{2 炭酸水凝固時の $\mathrm{CO}_{2}$ 気孔の生成}

所定の $\mathrm{CO}_{2}$ 濃度に調整した炭酸水を静かに凝固さ せ, $\mathrm{CO}_{2}$ 気孔の発生限界条件および気孔発生状況を調 查した. 溶液中の $\mathrm{CO}_{2}$ 濃度は $3000 \mathrm{mg} / l$ 以下に調整 したが，これは $\mathrm{CO}_{2}$ 濃度が約 $3400 \mathrm{mg} / l$ 以上になる 之溶液中の $\mathrm{CO}_{2}$ 分王が大気圧を超え液相より気孔が発 生離脱して条件が不安定になるためである. 実験条件と 結果を Table 1 に示す.

炭酸水を静かに凝固させた場合, $\mathrm{CO}_{2}$ 気孔は $\mathrm{G}_{1}=$ $230 \pm 20 \mathrm{mg} / l$ を遷移域として，これ以上の濃度で発生 した. ここでいう $\mathrm{CO}_{2}$ 気孔とは肉眼で識別可能な気孔 


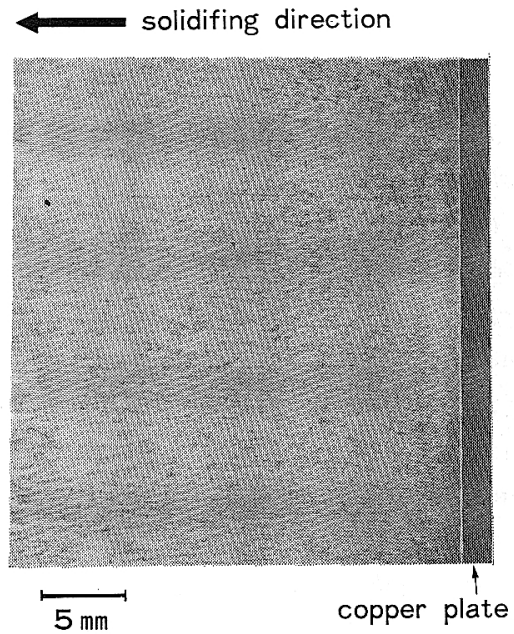

(a) $\mathrm{C}_{\ell}=275 \mathrm{mg} / \mathrm{\ell}$

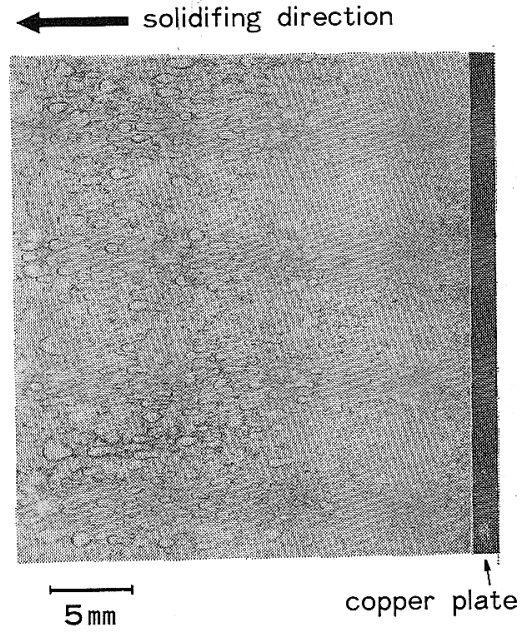

(b) $\mathrm{C}_{\ell}=1913 \mathrm{mg} / \mathrm{l}$

Photo. 1. Blowhole formation in static solidification.

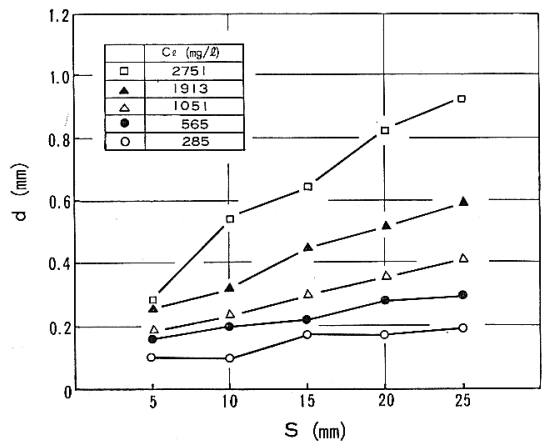

Fig. 3. Relationship between shell thickness and diameter of blowholes.

を意味するが，その発生開始位置はシェル厚約 $5 \mathrm{~mm} の$

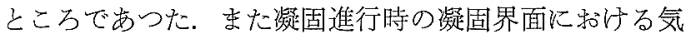
孔発生状況の観察によると比较的低 $\mathrm{CO}_{2}$ 濃度の Exp. No $A-4,8,10$ の実験では気液界面は平坦であり凝固の 進行とともに管状気孔が形成されたが，高濃度の Exp. No A-11，12 では凝固界面から微量の気泡が離脱浮上 する現象がみられた。

Photo. 1 (a)，(b) 飞それぞれ Exp. No A-4 ( $C_{1}$ $=275 \mathrm{mg} / l), \quad \mathrm{A}-10\left(C_{1}=1913 \mathrm{mg} / l\right)$, 飞和外る凝固シ ェルの断面写真を示す。気泡は凝固進行方向に成長乙概 して管状を是主る。気泡径は液中 $\mathrm{CO}_{2}$ 濃度に比例して 大きくなり，また凝固の進行ととも增大寸る傾向に市 ることがわかる。すなお当 Fig. 3 に示すように凝固初

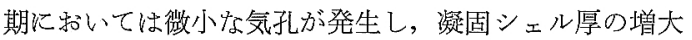
とともに気孔径ははぼ直線的炕增大するが，その勾配は

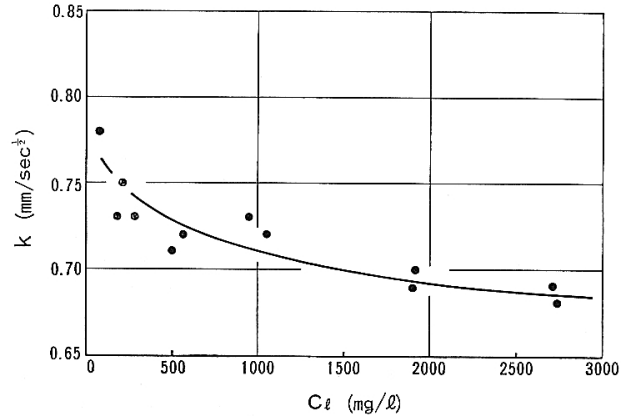

Fig. 4. Effect of $\mathrm{CO}_{2}$ content of aerated water on the solidification rate.

溶液中の $\mathrm{CO}_{2}$ 濃度に依存して括り，凝固シェルの見か 比重は， $\mathrm{CO}_{2}$ 濃度ととるに減少している. 本実験に 揖いて液相に比べ固相の体積が極めて小さく凝固進行時 の溶液中の $\mathrm{CO}_{2}$ 濃度の变化は汪とんど無視でさるもの であることを考光ると, 凝固界面での $\mathrm{CO}_{2}$ 気泡発生量 省決定する溶液中 $\mathrm{CO}_{2}$ 濃度と，発生した気泡を捕捉す る凝固シェルの成長速度により気孔形状が決をるものと 推定される.

静かに一方向凝固が進行した場合, 凝固シェル厚 $S$ は (2)式にしたがい変化した。

$$
S=k \sqrt{t} \text {....... }
$$

$k$ は凝固速度定数，t性凝固開始からの時間である。

Fig. 4 に種々の $\mathrm{CO}_{2}$ 濃度の炭酸水が凝固する时の $k$ 值を示した．溶液中の $\mathrm{CO}_{2}$ 濃度が高くなるにつれ $k$ 值 は低下する傾向にあるが，これは気孔発生量の增大に伴 い凝固シェルの熱伝導率が低下しているためと考㝋られ 
Table 2. Experimental results for suppression of $\mathrm{CO}_{2}$ blowholes.

\begin{tabular}{|c|c|c|c|c|c|}
\hline Exp.No & $\mathrm{C}_{\ell}(\mathrm{mg} / \ell)$ & $\mathrm{V}(\mathrm{cm} / \mathrm{sec})$ & $\mathrm{T}_{\mathrm{I}}$ ("C) & $\mathrm{T}_{\mathrm{II}}\left({ }^{\circ} \mathrm{C} \mathrm{C}\right)$ & blowholes \\
\hline$B-1$ & 897 & 5.1 & 3.5 & -72 & 0 \\
\hline-2 & 1.515 & 12.8 & 2.7 & -72 & 0 \\
\hline-3 & 1,014 & 2.6 & 3.0 & -73 & $\bullet$ \\
\hline-4 & 1.360 & 4.1 & 2.5 & -72 & - \\
\hline-5 & 1,574 & 2.6 & 2.5 & -72 & • \\
\hline-6 & 1.398 & 7.7 & 2.0 & -70 & 0 \\
\hline-7 & 650 & 2.6 & 3.5 & -68 & 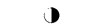 \\
\hline-8 & 1.558 & 5.1 & 3.0 & -69 & $\bullet$ \\
\hline-9 & 1.473 & 12.8 & 2.0 & -70 & 0 \\
\hline-10 & 1.080 & 6.4 & 2.4 & -68 & 0 \\
\hline-11 & 1,030 & 2.6 & 3.2 & -70 & 0 \\
\hline-12 & 1,497 & 5.1 & 3.3 & -70 & $\bullet$ \\
\hline-13 & 1,475 & 2.6 & 3.6 & -69 & $\bullet$ \\
\hline-14 & 1.710 & 10.2 & 2.0 & -69 & 1 \\
\hline-15 & 1,731 & 12.8 & 2.6 & -71 & 0 \\
\hline
\end{tabular}

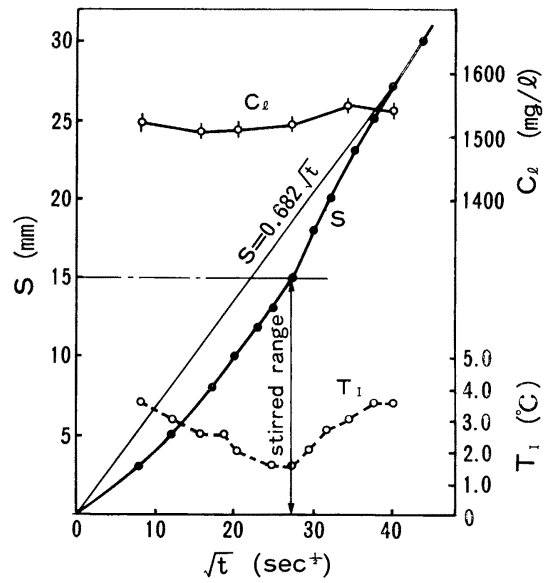

Fig. 5. Change of shell thickness, temperature, and $\mathrm{CO}_{2}$ content of aerated water with time.

る.

\section{$3 \cdot 3$ 流動による気孔の抑制}

炭酸水凝固時に凝固前面に所定の流速の流動を付与 し，流動による気孔の抑制について調査を行つた．実験 条件および実験結果を Table 2 に示す。すべての実験 にわたつて凝固シェル厚が $15 \mathrm{~mm}$ になるまで流速vの 流動を凝固界面に与光, その後攪挥を停止して静止凝固 させた．実験中の㠜固シェル厚，溶液中 $\mathrm{CO}_{2}$ 濃度，ハ ルク溶鋼中温度の時間変化の代表例 (Exp. No B-2) を Fig. 5 に示す。攪挥域に抋いては流動によるデンドラ イトの剪断が観察されないにもかかわらず凝固速度は低 下する。 また靦拌を停止した時点から凝固速度は増加す る傾向を示し，シェル厓 $30 \mathrm{~mm}$ の位置では本来の凝固 パターン $(S=0.68 \sqrt{t})$ に復帰している.これらは鋼の 連続鋳造における電磁攪拌下の凝固現象とよく対応して いる ${ }^{14)}$.また攪汼によりバルク溶鋼の温度が低下し，攪 汼停止により再び上昇する現象が確認された。（Table
2 中の $T_{I}$ はこれらの平均值を示した.) これらの現象 は流動により液相の熱伝達係数が増大することを考える と容易に理解できる.

流動による気孔抑制について行つた一連の実験で得ら れたシェル断面プロフィールの代表例をPhoto. 2 (a) 〜 (d)に示す. Photo. 2(a), (b)は $C_{1} \simeq 1000 \mathrm{mg} / l$ の時の気孔発生状況であり, $v=2.6 \mathrm{~cm} / \mathrm{s}$ においては流 速が不十分なため気孔の抑制は不十分であるが， $v=6.4$ $\mathrm{cm} / \mathrm{s}$ の流動を付与した部位においては気孔は完全に抑 制されていることを示している. Photo. 2 (c), (d) は $C_{1} \simeq 1500 \mathrm{mg} / l$ の条件で得られたものである. $v=5.1$ $\mathrm{cm} / \mathrm{s}$ では 気孔の抑制は不十分であり, $v=12.8 \mathrm{~cm} / \mathrm{s}$ になつて初めて完全に抑制される. しかし気孔が消隇し ていない部位でも流動の影響が全く無いわけではなく, 写真に見られるよらに気孔径, 密度は流動の無いものに 比べ減少している. Fig. 6 に $C_{1} \simeq 1500 \mathrm{mg} / 1$ の実験に 拉ける気孔径の流動による変化について示した，攪汼停 止後の気孔径はほぼ同等であるが攪找域であるシェル厚 $10 \mathrm{~mm}$ の位置に打いて $v=2.6 \mathrm{~cm} / \mathrm{s}$ で $d=0.15 \mathrm{~mm}$, $v=5.1 \mathrm{~cm} / \mathrm{s}$ で $d=0.10 \mathrm{~mm}$ となる.

Fig. 7 は本実験に拈ける気孔抑制の限界条件を溶液 中 $\mathrm{CO}_{2}$ 濃度と流速でまとめたものである，先に述べた ように静止凝固の場合, $C_{1}=230 \mathrm{mg} / l$ 程度が気孔発生 限界であるが，この濃度以上でも凝固前面に所定速度以 上の流れを付与させることにより気孔の無い凝固シェル を得ることが可能であり，その限界は $C_{1}=1000 \mathrm{mg} / l$ で $v=3 \mathrm{~cm} / \mathrm{s}, C_{1}=1500 \mathrm{mg} / l$ で $v=6 \mathrm{~cm} / \mathrm{s}$ である.

な打攪拌凝固時に凝固界面での気泡の観察を行つた が，流動による界面からの気泡の離脱浮上は認められな かつた. 以上の現象の観察結果, 低流速での気孔の小径 化, さらに一定流速以上での気孔抑制といら事実を合わ せて考慮すると，流動による気孔抑制のメカニズムとし て，物理的な気泡浮上ではなく，後述するごとく，流動 が凝固界面での溶質の濃化に影響を与えるためと推定さ れる。

\section{4. 考察}

溶鋼中で炭素および自由酸素は原子として存在し，こ れらが凝固界面に濃化して一定濃度以上になると一部は 反応して CO 気孔を発生し, 他は原子の状態あるいは 他元素との反応生成物となり固相中にトラップされると 考えられる. 一方, $\mathrm{CO}_{2}$ は水溶液中では $\mathrm{CO}_{3}^{2-}$ として 存在して打り, 凝固界面で濃化して $\mathrm{CO}_{2}$ 分圧が一定值 を越えると気孔を生成するとともに，一部は氷の結晶中 に $\mathrm{CO}_{2}$ 分子として侵入する. このように両者の系にお 


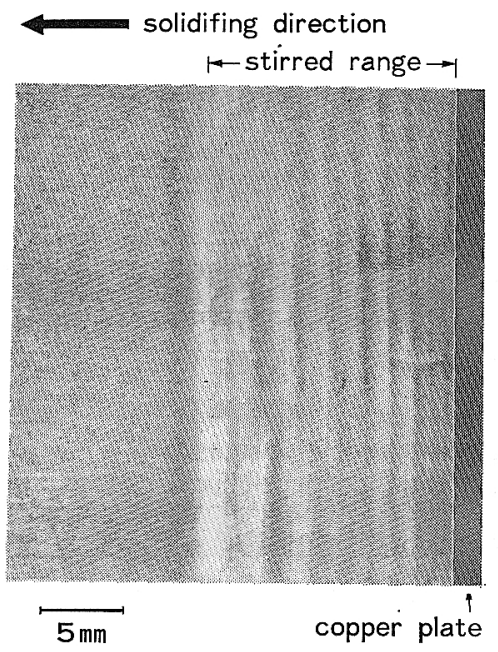

(a) $V=2.6 \mathrm{~cm} / \mathrm{sec}, \mathrm{C}_{\ell}=1030 \mathrm{mg} / \ell$

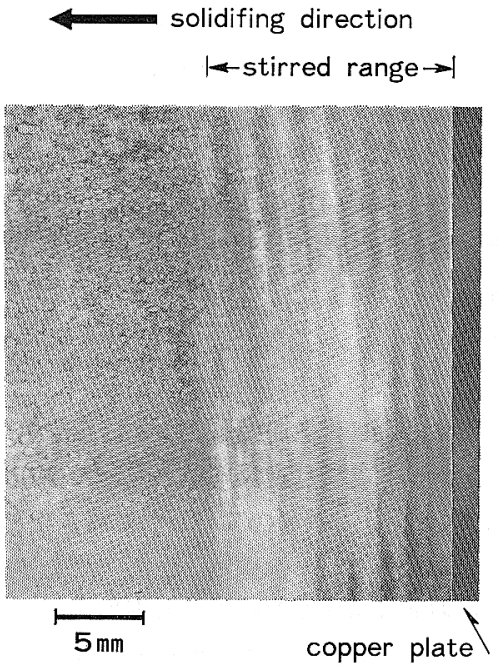

(c) $\mathrm{V}=5.1 \mathrm{~cm} / \mathrm{sec}, \mathrm{C}_{\ell}=1475 \mathrm{mg} / \ell$

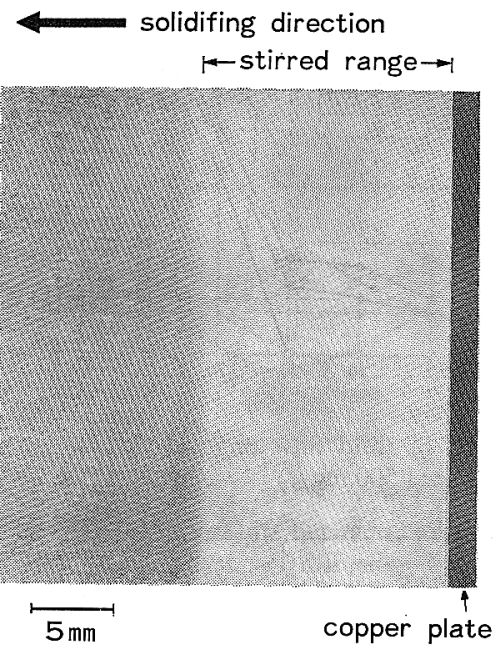

(b) $V=6.4 \mathrm{~cm} / \mathrm{sec}, \mathrm{C}_{\ell}=1080 \mathrm{mg} / \ell$ :

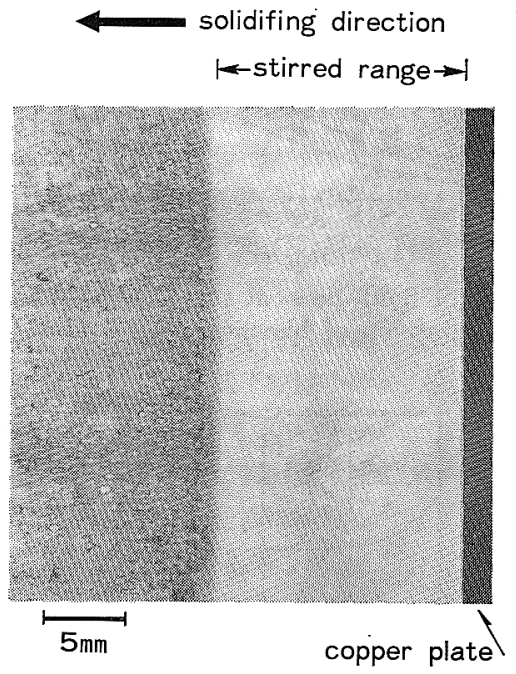

(d) $\mathrm{V}=12.8 \mathrm{~cm} / \mathrm{sec}, \mathrm{C}_{\ell}=1473 \mathrm{mg} / \ell$

Photo. 2. Suppression of blowhole with stirring of liquid.

いては溶質の固液分配や反応機情に関して幾つかの相異 点が挙げられるが，ここでは以上示した実験結果に基づ さ(1) 凝固時の $\mathrm{CO}_{2}$ 気孔の生成機構，（2）流動による 気孔抑制の機樍について考察を行つた.

\section{$4 \cdot 1$ 凝固時の $\mathrm{CO}_{2}$ 気孔発生に関する考察}

凝固進行時の観察結果から㠜固界面は添ぼ平滑とみな すことができることにより，凝固界面での溶質濃化扣よ び固液分配に関して Fig. 8 のプロフィールを想定し BURTON の式占)が成立すると仮定与る。

$$
\ln \left\{\left(1 / n_{\mathrm{CO}_{2}}^{\circ}-1\right) /\left(1 / n_{\mathrm{CO}_{2}}-1\right)\right\}=f \cdot \delta / D_{\mathrm{CO}_{2}} \cdots
$$

ただし $f$ は凝固速度， $D_{\mathrm{CO}_{2}}$ は溶液中での $\mathrm{CO}_{2}$ の拡 散係数， $\delta$ は凝固界面での拡散境膜厚み， $n_{\mathrm{CO}_{2}}$ は $\mathrm{CO}_{2}$

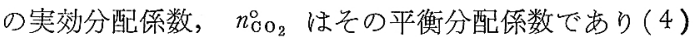
式で与点られ。.

$$
n_{\mathrm{CO}_{2}}^{\circ}=C_{\mathrm{S}} / C_{\mathrm{i}}
$$

ここで $C_{1}$ は凝固界面での $\mathrm{CO}_{2}$ 濃度であるが，これ と平衡する $\mathrm{CO}_{2}$ 分圧 $P_{\mathrm{CO}_{2}}$ との関係次式のようにな る.

$$
C_{\mathrm{i}}=\left(P_{\mathrm{CO}_{2}} \cdot M_{\mathrm{CO}_{2}} \times 10^{6}\right) /\left(H-P_{\mathrm{CO}_{2}}\right) \cdot M_{\mathrm{H}_{2} \mathrm{O}} \cdots(5)
$$

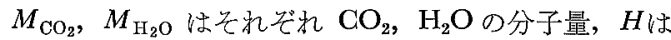




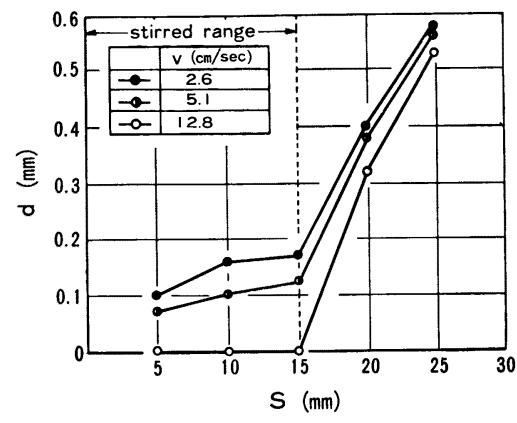

Fig. 6. Effect of fluid flow on the diameter of blowholes. $\left(C_{1} \simeq 1500 \mathrm{mg} / l\right)$

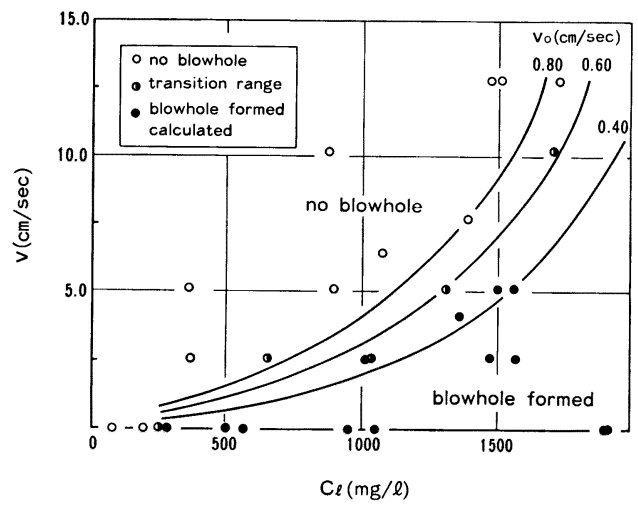

Fig. 7. Effect of fluid flow at the solidification front on the supression of blowholes.

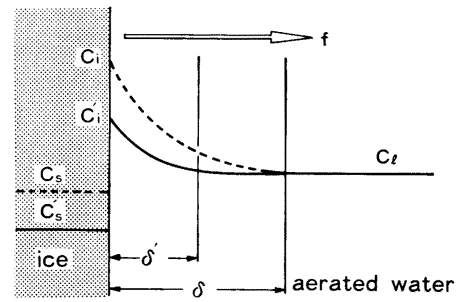

\begin{tabular}{l|c|c} 
& without stirring & stirring \\
\hline $\begin{array}{l}\mathrm{CO}_{2} \text { content at the } \\
\text { solidification front }\end{array}$ & $\mathrm{C}_{\mathrm{i}}$ & $\mathrm{C}_{\mathrm{i}}^{\prime}$ \\
$\begin{array}{l}\mathrm{CO} \text { content of } \\
\text { solidified shell }\end{array}$ & $\mathrm{C}_{5}$ & $\mathrm{C}_{\mathrm{s}}^{\prime}$ \\
$\begin{array}{l}\text { thickness of diffusion } \\
\text { boundary layer }\end{array}$ & $\delta$ & $\delta^{\prime}$
\end{tabular}

Fig. 8. Profile of solute concentration at the solidification front.

Henry 定数である. $H$ は希薄溶液においては温度のみ の関数であり, $0^{\circ} \mathrm{G}$ において $\left.H=72816\right)$ である.

(1)，(4)，(5)式より(6)式が得られる.

$$
n_{\mathrm{CO}_{2}}^{\circ}=n_{\mathrm{CO}_{2}} \cdot C_{1} \cdot M_{\mathrm{H}_{2} \mathrm{O}}\left(H-P_{\mathrm{CO}_{2}}\right) / M_{\mathrm{CO}_{2}} \cdot P_{\mathrm{CO}_{2}}
$$

A.W. Hills らは酸素を含有する水の凝固実験を行
い, $\mathrm{O}_{2}$ 気孔発生時の凝固界面における $\mathrm{O}_{2}$ 濃度を計算 しているが，その時の $\mathrm{O}_{2}$ 分圧はほぼ大気圧と一致する ことを報告している ${ }^{13)}$. 本実験に氺ける溶媒も水であ り，溶質である $\mathrm{CO}_{2}$ も $\mathrm{O}_{2}$ と同様，非極性分子である ことから凝固界面に拈ける気孔生成に関する挙動も大き くは異ならないものと考古, 気孔発生に必要な $\mathrm{CO}_{2}$ 分 压を $1 \mathrm{~atm}$ と仮定する. $\mathrm{CO}_{2}$ 気孔の発生限界に拈い $\tau$, その時のバルク溶液中の $\mathrm{CO}_{2}$ 濃度が $230 \mathrm{mg} / l$, また気孔発生開始位置は凝固シェル厚が約 $5 \mathrm{~mm}$ の位置 であるという実験結果に基づき，Fig. 2 よりその時の 実効分配係数の值が 0.12 であることが分かるが，これ らの限界条件を(6)式に代入することにより任意の凝固 位置での溶質濃化度 $I_{\mathrm{j}}$ を求めることが可能となる.

$$
I_{\mathrm{j}}=C_{\mathrm{i}} / C_{1}=n_{\mathrm{CO}_{2}} / n_{\mathrm{CO}_{2}}^{\circ}
$$

次に先に示した凝固時の $\mathrm{CO}_{2}$ 気泡の観察結果より, 気泡生成のモデルを作る、すなわち本実験で対象とする 気泡は凝固界面から離脱することなく成長し，凝固方向 の気泡の成長速度は凝固速度と一致すると考光，ディス ク状気泡のつながりで気泡形状をシミュレートすると (8) 式が成立する.

$$
\Delta V_{\mathbf{j}}=\pi \cdot f \cdot \Delta t\left(d_{\mathrm{j}} / 2\right)
$$

ここで $\Delta V_{\mathbf{j}}$ は $\Delta t$ 間に生成したディスク状の気泡要 素 $j$ の体積であり，その直径が $d_{\mathbf{j}}$ である．また $f$ は凝 固が (2)式にしたがつて進行する場合, $j$ 位置でのシェ ル厚 $S$ を $S_{\mathrm{j}}$ とすると(9)式のように表される.

$$
f=(d S / d t)_{t=t_{\mathrm{j}}}=k^{2} / 2 S_{\mathrm{j}}
$$

また $\mathrm{CO}_{2}$ ガスの発生速度は一般に一次反応と考えら れるが，ここでは逆反応を無視して $(10)$ 式のように簡略 化する.

$$
\Delta V_{\mathrm{j}} / \Delta t=K C_{\mathrm{ij}} R T / P=K^{\prime} C_{1} \mathrm{I}_{\mathrm{j}}
$$

な沶 $R$ は気体定数， $T$ は凝固界面での温度，Pは大気 圧， $K$ は $\mathrm{CO}_{2}$ ガスの反応速度定数， $C_{\mathrm{i} j}$ は $j$ 位置にお ける凝固界面での溶質濃度である。 $R, T, P$ は本実験条 件の下では一定であるので $K^{\prime}=K \cdot R \cdot T / P$ とし, また $j$ 位置での濃化度を $I_{\mathrm{j}}$ とする. $(8) \sim(10)$ 式を $(\Delta V /$ $\Delta t)$ で整理すると (11) 式が得られる.

$$
d_{\mathrm{j}}^{2}=8 K^{\prime} C_{1} S_{\mathrm{j}} I_{\mathrm{j}} / \pi k^{2} \text {. }
$$

$I_{\mathrm{j}}$ は ( 7 )式より計算でき，凝固シェル厚との関係は Fig. 9 の $v=v_{0}$ のよらになる. シェル厚 $5 \sim 30 \mathrm{~mm}$ の 位置では $I_{\mathrm{j}}$ は $12 \sim 15$ 程度となることが分かる.

以上の結果に基づき Fig. 10 に凝固各位置での気孔径 の測定值を $\sqrt{S_{\mathrm{j}} \cdot I_{\mathrm{j}}}$ の值に対してプロットした. なお 同図中には(11)式による計算結果を実線で示した. ここ で使用した $K^{\prime}$ の值は $2.53 \times 10^{-4} \mathrm{~cm}^{3} / \mathrm{s}$ である. 実測 值と計算結果は非常に良く一致しており，本実験条件下 


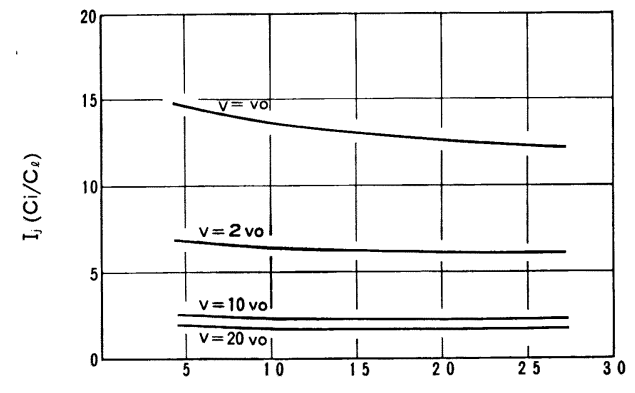

$\mathrm{S}_{\mathrm{j}}(\mathrm{mm})$

Fig. 9. Relationship between shell thickness and solute concentration at the solidification front.

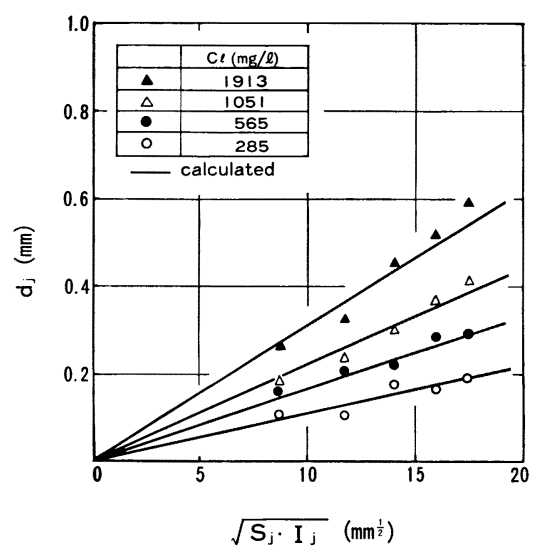

Fig. 10. Relationship between $V \overline{S_{\mathrm{j}} \cdot I_{\mathrm{j}}}$ and $d_{\mathrm{j}}$.

での気孔生成の現象をこのモデルにより説明することが できることを示している.

\section{$4 \cdot 2$ 流動による気孔抑制についての考察}

流動による気孔抑制に関する実験結果より Fig. 8 に 示すように, 凝固前面に付与された流動によつて凝固界 面での溶質の濃化度が低下する機構を考える.

凝固界面での溶質の濃化度は (1)，（3)，（4)，（7） 式より(12)式のように表される.

$$
I_{\mathrm{j}}=1 /\left\{n_{\mathrm{CO}_{2}}^{\circ}+\left(1-n_{\mathrm{CO}_{2}}^{\circ}\right) \exp \left(-\cdot f \cdot \delta / D_{\mathrm{CO}_{2}}\right)\right\}
$$

また流速 vの流動下の凝固界面での拡散境膜厚み $\delta$ は 一般に(13)式で表される.17)

$$
\delta=\alpha / \sqrt{v}
$$

ここで $\alpha$ は凝固速度 $f$ の関数であり, かつ静止凝固時 においても凝固前面には流速 $v_{0}$ の自然対流が生じてい ると仮定すると(12)，(13)式より $\alpha$ は(14)式のように表 される.

$$
\alpha=\left(D_{\mathrm{CO}_{2}} \sqrt{v_{0}} / f\right) \ln \left\{\left(1-n_{\mathrm{CO}_{2}}^{\circ}\right) /\left(1 / I_{0}-n_{\mathrm{CO}_{2}}^{\circ}\right)\right\}
$$

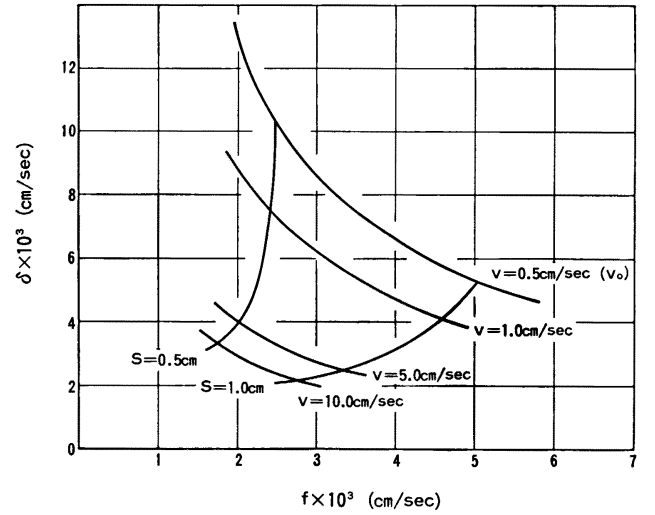

Fig. 11. Relationship between solidification rate and film thickness at diffusion boundary under fluid flow.

ただし $I_{0}$ は静止凝固時の凝固界面での溶質濃化度で ある.（12），(13)，(14)式より流速 vの流れが凝固界面 に存在する場合の界面での濃化度 $I_{\mathrm{v}}$ は次式のようにな る.

$$
\begin{aligned}
I_{\mathrm{v}} & =1 /\left\{\left(1 / I_{0}-n_{\mathrm{CO}}^{\circ}\right) \sqrt{v_{0} / v} \cdot\left(1-n_{\mathrm{CO}}^{\circ}\right) 1-\sqrt{v_{0} / v}\right. \\
& \left.+n_{\mathrm{CO}_{2}}^{\circ}\right\} \cdots \ldots \ldots \ldots \ldots \ldots \ldots \ldots \ldots \ldots \ldots \ldots \ldots \ldots \ldots \ldots \ldots \ldots \ldots \ldots \ldots \ldots \ldots \ldots \ldots \ldots \ldots \ldots
\end{aligned}
$$

この式に基づき流速 $v=2 v_{0} ， 10 v_{0}$ ，および $20 v_{0}$ の時 の凝固界面での濃化度を計算し Fig. 9 に示した. 流動 による濃化度低下の効果は大きく $v=2 v_{0}$ で静止凝固時 の半分程度となつている. しかしながら $v=20 v_{0}$ 以上の 流速では濃化度の低下幅は小さく，効果は飽和状態にな つている.

次に静止凝固時に凝固速度定数 $k=0.71 \mathrm{~mm} / \mathrm{s}^{1 / 2}$ とな る系に颃いて凝固前面に流動を付与した場合の凝固速度 と拡散境膜厚みの関係についての計算例を Fig. 11 に示 す.ただし $v_{0}=0.5 \mathrm{~cm} / \mathrm{s}$ とし, $0^{\circ} \mathrm{C}$ の水中の $\mathrm{CO}_{2}$ の 拡散係数 $D_{\mathrm{CO} 2}$ としては D.M. HimmelblaU ${ }^{18)}$ の值 $\left(D_{\mathrm{CO} 2}=0.95 \times 10^{-5} \mathrm{~cm}^{2} / \mathrm{s}\right)$ を使用した. 流動による凝 固速度 $f$ の変化は実測值を使用した。流動により $(f \cdot \delta)$ の值は大幅に低下しており，またこの程度は凝固シェル 厚により異なることが分かる.

最後にこれらの関係を用い $\mathrm{CO}_{2}$ 気孔の発生限界に及 ぼす流動の影響について検討した（5)（7)（15)式より 凝固前面の $\mathrm{CO}_{2}$ 分圧 $P_{\mathrm{CO}_{2}}$ は(16)式のように表され る.

$$
\begin{aligned}
& P_{\mathrm{CO}_{2}}=M_{\mathrm{H}_{2} \mathrm{O}} \cdot H /\left[M_{\mathrm{H}_{2} \mathrm{O}}+\left(M_{\mathrm{CO}_{2}} / C_{1}\right)\right. \\
& \quad \times 10^{6}\left\{\left(1 / I_{0}-n_{\mathrm{CO}_{2}}^{\circ}\right) v \overline{v_{0} / v}\left(1-n_{\mathrm{CO}_{2}}^{\circ}\right) 1-v \overline{v_{0} / v}\right. \\
& \left.\left.\quad+n_{\mathrm{CO}_{2}}^{\circ}\right\}\right] \ldots \ldots \ldots \ldots \ldots \ldots \ldots \ldots \ldots \ldots \ldots \ldots \ldots \ldots \ldots \ldots \ldots \ldots \ldots \ldots \ldots \ldots \ldots \ldots \ldots \ldots \ldots
\end{aligned}
$$

先に述べたように気孔発生は $P_{\mathrm{CO} 2} \geq 1 \mathrm{~atm}$ 以上でお こると仮定し, 静止凝固時に凝固界面で生ずる自然対流 
の流速 $v_{0}=0.4,0.6$, および $0.8 \mathrm{~cm} / \mathrm{s}$ の場合につい て, $\mathrm{CO}_{2}$ 気孔の発生限界に拈ける溶液中の $\mathrm{CO}_{2}$ 濃度と 流速の関係を計算して Fig. 7 に示した. $v_{0}=0.6 \mathrm{~cm} / \mathrm{s}$ の場合の計算例が同図中にプロットした実測值と最も良 く一致しているが，この程度の自然対流は本実験条件下 では十分抗こりらるものである.これらの結果により本 モデルの考え方は妥当であると考えられる.

なお本モデル実験結果に基づく実用鋳片の CO 気孔 発生とその抑制に関しては別途報告する予定であるが， 以上に述べた結果は連鋳の鋳片表面での CO 気孔抑制 のためには凝固前面の流動，すなわち鋳型内溶鋼流動が 極めて有力な手段となることを示すものである.

\section{5. 結言}

鋳片凝固時の $\mathrm{CO}$ 気孔の発生, および流動による気 孔抑制のメカニズム解明の手がかりとすべく炭酸水によ るモデル実験を行い次の結果を得た.

1 ) 炭酸水凝固時の $\mathrm{CO}_{2}$ 気孔発生, および抑制機構 の定量化のための基礎データとすべく $\mathrm{CO}_{2}$ の固液分配 について実験を行い, 凝固シェル中および溶液中の $\mathrm{CO}_{2}$ 濃度の分析結果より $\mathrm{CO}_{2}$ の実効分配係数を求めた. さ らにこれらの結果と気孔発生限界条件より平衡分配係数 を推定した。

2 ) 種々の $\mathrm{CO}_{2}$ 濃度の炭酸水を静止状態で一方向凝 固させ, 気孔発生状況について調查した。気孔形状はほ ぼ管状となり, その径は溶液中 $\mathrm{CO}_{2}$ 濃度および凝固速 度により变化する。 また凝固速度定数も $\mathrm{CO}_{2}$ 濃度とと もに変化するが，これは気孔発生にともなら凝固シェル の熱伝達率の低下によるものである.

3 ）炭酸水の一方向凝固時に凝固前面に流動を与える ことにより気孔径は小さくなり，所定の流速以上になる と気孔は完全に消隇する，また気孔抑制に必要な流速の 限界值は溶液中 $\mathrm{CO}_{2}$ 濃度により変化する．な挔本実験 条件下では流動による凝固前面からの気泡の離脱は観察 されなかつた.
4) これらの基礎データ，観察結果に基づき気孔の成 長，流動による抑制について考察を行つた．気孔形状は 凝固速度之凝固界面に濃化した $\mathrm{CO}_{2}$ による気泡発生の ポテンシャルによつて決定される，また流動により凝固 界面の $\mathrm{CO}_{2}$ の濃化度が低下するといら機構により気孔 抑制の現象を説明することが可能である.

\section{交献}

1 ) 竹内栄一, 藤井博務, 大橋徹郎, 平偂照祥, 堀井 義信：鉄と鋼，65 (1979), S 754

2 ) 竹内栄一, 藤井博務, 大橋徹郎, 堀井義信, 安江 幹，山広実留：鉄と鋼，66 (1980)， S 135

3 ) 河野拓夫, 長澤元夫, 椿原 治, 細野和典, 江坂 一涁, 石飛精助：鉄と鋼，67 (1981), p. 1241

4 ）竹内栄一，藤井博務，大橋徹郎，木村一茂，高島 靖, 山広実留: 鉄と鋼, 66 (1980), S 797

5 ) 竹内栄一, 藤井博務, 有馬良士, 大平俊郎, 大橋 徹郎，山広実留：鉄と鋼，67 (1981)，S 201

6 ) 森一美, 平岩 正, 野村宏之: 鉄之鋼, 61 (1975), p. 2952

7 ）野村宏之, 森一美：鉄と鋼，64(1978), p.1143

8 ) 野村宏之, 森一美, 中島敏洋: 鉄之鋼, 65 (1979), p. 583

9 ) D. Burns and $J$. BeEch: Ironmaking Steelmaking, 4 (1974), p. 239

10) B. HARKNess and $A$. Nicholson: JISI, 209 (1971), p. 692

11) H. Knilppel and F.E. Berhard: Arch. Eisenhüttenwes, 34, (1963), p. 325

12) A.E. Garte: Proc. Phys. Soc, 77, S 757

13) A.W. Hills and I.C. Wells: Kinetik metallurgisher Vorgange bei der Stahlherstellung (1972), p. 438 [Verlag Stahleisen, Düsseldorf]

14）藤井博務，大橋徹郎：鉄と鋼，64 (1978)，S 646

15) J.A. Burton, R.C. Prim, and W.P. Slichter: J. Phys. Chem, 21 (1953) 11, p. 1987

16) Irternational Critical Tables, vol. 3, p. 260

17）藤井博務，大橋徹郎：鉄と鋼，64 (1978), S 197

18) D.M. Himmelblau: Chem. Rev, 64 (1964), p. 527 